\title{
The Psychological Effects of Traumatic Brain Injury on the Quality of life of a Group of Spouses/Partners
}

\author{
Tamar Wedcliffe and Eleanor Ross
}

Department of Speech Pathology and Audiology, University of the Witwatersrand

\begin{abstract}
This study explored the psychosocial impact of traumatic brain injury on the perceived quality of life of a purposefully selected group of 14 spouses/partners of head injured persons by means of a self-administered questionnaire. Analysis of responses revealed that spouses/partners' altered communication patterns were perceived to have affected interpersonal relationships and quality of life extensively, indicating the need for speech-language therapy. Decreased income was noted due to the low incidence of return to work. Participants reported changes in family relationships, particularly between the injured person and their children as well as deterioration in marital relationships, suggesting the necessity for family therapy and marital counselling. Various emotional reactions were documented in response to injury. Yet most respondents expressed acceptance of their new roles and responsibilities despite the difficulties entailed. Since injured persons were dependent on their spouses/partners to a large extent, most of the latter reported feeling tied down. Loneliness predominated as a social consequence despite the support of pre-injury friendships. In terms of coping resources, friends, family, religion and support groups were perceived to be most effective. Results are discussed in terms of their clinical implications for psychosocial rehabilitation and spouse/partner counselling.
\end{abstract}

\section{OPSOMMING}

Hierdie studie het die psigososiale impak van traumatiese breinbesering op die lewenskwaliteit van' ' $n$ spesifiek geselekteerde groep van 14 eggenotel gesellel maats van breinbesserde persone ondersoek deur middel van ' $n$ selftoegepaste vraelys. ' $n$ Analise van die uitslae het getoon dat die eggenote / geselle / maats se ervaring van die veranderde kommunikasiepatrone ' $n$ groot invloed op interpersoonlike verhoudinge en lewenskwaliteit gehad het, wat aandui dat spraak-taalterapie nodig is. Verminderde inkomste is opgemerk, as gevolg van die lae hoeveelheid terugkeer werk töe. Deelnemers het veranderinge in familieverhoudinge gerapporteer, veral tussen die beseerde persone en hul kinders, sowel as ' $n$ verswakking in huweliksverhoudinge, wat aandui dat gesinsterapie en huweliksberading nodig is. Verskeie emosionele reaksies is beskryf teenoor die besering. Tog het die meeste respondente aanvaarding van hulle nuwe rolle en verantwoordelikhede uitgedruk, ten spyte van die probleme wat ondervind is. Aangesien die beseerde persone in ' $n$ groot mate van hulle eggenote / geselle / maats afhanklik is, het die meeste deelnemers beskryf dat hulle vasgevang voel. Eensaamheid was die oorwegende sosiale gevolg, ten spyte van die ondersteuning van vriendskappe voor die besering.' In terme van bekampingsbronne, is vriende, familie, godsdiens en ondersteuningsgroepe as die mees effektief beskou. Resultate is bespreek in terme van kliniese implikasies vir psigososiale rehabilitasie en eggenoot /geselle-berading.

KEY WORDS: traumatic brain injury, spouses, partners, quality of life

\section{INTRODUCTION}

In South Africa, the incidence of traumatic brain injury (TBI), which includes both penetrating injuries from sharp objects as well as closed head injuries from blunt objects is regarded as very high, namely 316 per 100000 persons (Nell \& Brown, 1990). Furthermore, improved medical care has made it increasingly likely that persons with severe head injuries will survive. Unfortunately, a considerable number are likely to remain disabled, placing a burden on their families (McKinlay, Brooks, Bond, Martinage, \& Marshall, 1981). Relatively good physical recovery has been found to occur with most closed head injured patients. However, a significant number remain with psychosocial deficits and/or cognitive impairment (Ponsford, 1995a). After traumatic brain injury, many patients who appear to be functioning normally may have subtle communicative and social problems (Penn, Jones, Schmaman, Vyncke, Watt, \& Fridjhon, 1998). Since these cognitive and behavioural problems may not be immediately visible (Tate, Lulham, Broe, Strettles, \& Pfaff, 1989), professionals may be quick to gloss over them, underestimating their impact on the patient's functioning within the family environment. 
As early as 1978, Lezak (1988) documented specific reactions experienced by relatives living with chronically disabled brain injured individuals, which included feeling trapped, socially isolated, abandoned by extended family and abused by the patient. Indeed, more than two-thirds of relatives in a study by McKinlay, et al. (1981) felt moderately to severely burdened by mental and behavioural changes in their family member one year after injury. Since then, studies have shown that traumatic brain injury creates an enormous burden on family life which increases rather than decreases over time (Brooks, McKinlay, Symington, Beattie, \& Campsie, 1987).

When spouse and parent caregiver responses were compared, spouses consistently reported a greater number of behavioural problems which were perceived to have increased in severity over time (Hall, Karzmark, Stevens, Englander, O'Hare, \& Wright, 1994). Interestingly, Panting and Merry (1972), and later, Thomsen (1984), asserted that marital relationships appeared to be less resilient to the effects of strain than parent-child relationships. Oddy, Humphrey and Uttley (1978) found that marital relationships and family life appeared to withstand the changes resulting from brain injury that had occurred six months before. Nonetheless, there is extensive evidence of deterioration or dissolution of marital relationships following traumatic brain injury (Thomsen, 1984). The frequently reported marital, social, financial and emotional difficulties may have a considerable impact on the quality of life of the spouse/partner of a brain-injured individual.

Much emphasis has been placed on the issue of improving quality of life as a realistic goal in rehabilitation (Pain, Dunn, Anderson, Darrah, \& Kratochvil, 1998). According to the World Health Organization (1993), quality of life may be defined as the perception of individuals of their positions in life in the culture and value system in which they live, relative to their goals, expectations, standards and concerns. It is said to be a broad ranging concept affected in a complex way by individuals' physical health, psychological state, level of independence, social relationships and their relationships to salient features in their environment (WHO, 1993). This definition encompasses the propositions of those who view quality of life as the impact of a perceived health state on the ability to live a fulfilling life; the affective response to a role situation and the discrepancy between an individual's desired and actual circumstances (Bowling, 1995). However, a shortcoming of this definition is the fact that no mention is made of the link between communication and quality of life.

Many studies have focused on the quality of life and psychosocial functioning of head injured persons (for example: Klonoff, Costa, \& Snow, 1986; Tate et al., 1989). Researchers have also investigated aspects of the psychosocial functioning of the relatives of persons who have sustained traumatic brain injury (for example: Thomsen, 1984; Livingston, Brooks, \& Bond, 1985; Brooks et al., 1987). Many of the studies assessing the latter have used mood rating or stress rating scales. Indeed, the use of a single measure of burden was evident in a study by Brooks and McKinlay (1983), who found that personality changes following brain injury were associated with high subjective burden in relatives.
Single ratings of burden or stress may be criticized as being superficial and having limited clinical value since they fail to describe the manifestations of strain which require intervention. More detailed studies are necessary to gain knowledge regarding the specific parameters affecting psychosocial adjustment in order to design effective rehabilitation programmes for patients and their families. One such study by Livingston, et al. (1985) investigated the burden of relatives in a more detailed manner, considering aspects of psychiatric and social functioning. Similarly, in their study exploring predictors of burden on caregivers, Brooks, et al. (1987) described parameters such as language and physical dependence. However, although detailed, these studies neglected many factors affecting quality of life such as financial issues, family dynamics and strategies to alleviate burden. In addition, the relatives and caregivers in these studies were not necessarily the spouses / partners of the injured person. A recently published South African study compared the changes in emotion and daily function experienced by a group of partners of brain injured individuals with a group whose partners had experienced spinal cord injuries (Levor \& Jansen, 1999). The study explored the stress levels and restrictions of social and sexual life of partners in order to identify the needs and available support for each subgroup. However, as in previous studies, detailed information regarding issues such as financial concerns, family relationships and most importantly, communication was not obtained.

Since quality of life has been defined and operationalized in so many different ways, the present study endeavoured to address weaknesses identified in earlier studies and provide a broader perspective on quality of life of spouses/partners by combining domains such as changes in communication patterns, financial variables, physical, social, emotional and psychological functioning and coping strategies. Quality of life was operationally defined as the contribution and interaction of these particular factors which were selected following consultation with experts in the field, and with a subject who was not included in the final sample, as well as on the basis of extensive reviews of the literature and research on the topic, for example: communication (Wertz, LaPointe \& Rosenbek, 1984); financial factors (Bowling, 1995); family relationships (Panting \& Merry, 1972); emotional, physical and social factors (Bowling, 1995); and coping (Hall et al., 1994).

Currently in South Africa, there has been a fundamental shift in the way that disabled people are viewed. The emphasis has moved away from the individual medical perspective to the social model which considers the human rights and development of not only those with disabilities, but also of their families (White Paper on an Integrated National Disability Strategy, 1997). Based on this model, the current study sought to discover the effects of brain injury on the spouse/partner and family of the injured person. Insight into the changes in family life, particularly the change in quality of the spouse's/partner's life as a result of traumatic brain injury has direct clinical, relevance. Specific communicative, cognitive or behavioural issues which are perceived by spouses/partners to interfere with adaptive family functioning might be targeted in therapy with the brain injured individual, as well as in family or spouse counselling sessions. By understanding family 
needs and expectations, staff might be able to provide the appropriate education and support to facilitate the setting and achievement of realistic goals for rehabilitation. It was also anticipated that, as a result of increased knowledge of the factors that appeared to correlate with a richer quality of life, professionals would be better equipped to advise families regarding strategies that might be used to improve their lives.

Communication is a primary ingredient for a favourable quality of life, fulfilling an essential role in the adjustment and psychological well being of humans in their social context (Swindell, Holland, \& Reinmuth, 1994). It is thus considered the domain of a speechlanguage therapist to investigate issues affecting quality of life such as social life, marital relationship and financial independence, many of which rely heavily on intact communication processes. For these reasons, the study endeavoured to investigate the impact of traumatic brain injury on the quality of life of the injured person's spouse/partner. Various psychosocial concerns and perceptions of the spouse/partner that might contribute to quality of life were explored including financial, communication, social and marital factors as well as family functioning and coping mechanisms.

\section{METHODOLOGY}

\section{AIM}

To investigate the psychosocial impact of traumatic brain injury on the quality of life of spouses/partners living with them.

\section{Sub-aims}

In order to address the above aim, the following sub-aims were formulated:

1. To elicit subjects' perceptions regarding the communicative abilities of the individual with TBI which might contribute to psychosocial problems.

2. To obtain information on the perceived impact of the TBI on the occupational status of the injured individual and the financial status of spouses / partners.

3. To explore perceived changes in family dynamics, roles and responsibilities as a result of the TBI.

4. To gauge the perceived influence of the TBI on marital or common law relationships.

5. To determine the perceived emotional effects of the TBI on the individual's spouse/partner. 6. To assess the influence of the TBI on the spouses/partners' social life.

6. To explore coping mechanisms of the subjects surveyed.

\section{RESEARCH DESIGN}

An exploratory-descriptive, single group research design, involving the use of a self-administered questionnaire, was employed to investigate the aims of this study. This design was chosen because of the difficulties experienced in recruiting sufficient subjects who met the subject selection criteria, as well as the need for in-depth coverage of a wide range of dimensions thought to impact on quality of life.

\section{Subject selection criteria}

Subjects were selected according to the following criteria:

Marital status: Subjects were required to have been married civilly or by common law at the time of the injury as this study focused specifically on partners of persons with TBI.

Type of injury of spouse/partner: Subjects' spouses/partners were required to have sustained a brain injury due to trauma, rather than cerebrovascular accident, where damage is usually more focal and specific than the damage affecting many aspects of physical, cognitive and psychological functioning (Hagen, 1984) that results from acceleration-deceleration injuries.

Time since injury: At least two months had to have passed since the injury to allow the initial shock of the injury as well as many of the patient's cognitive impairments to have passed (Hagen, 1984), giving way to more long-term psychosocial concerns on which this study focused.

Additional disabilities: Subjects were required not to present with any additional known disabilities that might have confounded the results.

Living status: The subjects needed to physically live with the individual with TBI at the time of the study.

Subject selection procedure

The researcher obtained a sample of 33 persons by conducting record reviews of persons with TBI who had been discharged from various rehabilitation hospitals in Johannesburg as well as by approaching a support group for head injured persons and their families, a nursing home for the long-term care of head-injured patients, speech therapists and a neuropsychologist. Although it is acknowledged that non-representative, non-probability, purposive sampling may limit generalisation of the results of the study, it was anticipated that many of the subjects' psychosocial concerns might apply to other persons with TBI who had attended rehabilitation programmes.

\section{Description of subjects}

Of the 33 questionnaires that were sent out to potential respondents, 14 were returned, representing an adequate response rate (Babbie, 1995). Demographic information obtained from these 14 subjects is set out in Table 1 . The majority of subjects were females. Ages of subjects ranged from 20 to 58 years. Time since injury ranged from between 5 months to 10 years. They had lived with their spouses/partners from between 1 year to 35 years. All of the traumatically brain injured spouses had received speech-language therapy.

\section{RESEARCH INSTRUMENTATION}

A self-administered questionnaire was selected as a means of data collection, a copy of which is set out in Appendix A. Original questions were supplemented with items generated from existing scales (Records, 1997), on the basis of research literature (Livingston et al., 1985). The questionnaire was divided into eight sections in order to elicit information on subjects and their spouses/partners as well as obtain data in respect of the seven sub-aims of the study. 
Table 1: Demographic Profile of Subjects $(\mathrm{N}=14)$

\begin{tabular}{|c|c|c|}
\hline & Category & Number of Subjects \\
\hline \multirow[t]{7}{*}{ Age of subjects } & $20-25$ years & 2 \\
\hline & $26-30$ years & 2 \\
\hline & $31-35$ years & 0 \\
\hline & $36-40$ years & 3 \\
\hline & $41-45$ years & 3 \\
\hline & $46-50$ years & 2 \\
\hline & $50+$ years & 2 \\
\hline \multirow[t]{2}{*}{ Gender of subjects } & Male & 2 \\
\hline & Female & 12 \\
\hline Duration of marriage/ & $1-5$ years & 3 \\
\hline living together & 6-10 years & 3 \\
\hline & 11-15 years & 1 \\
\hline & $16-20$ years & 1 \\
\hline & $21-25$ years & 4 \\
\hline & 26-30 years & 1 \\
\hline & $31-35$ years & 1 \\
\hline \multirow{2}{*}{$\begin{array}{c}\text { Age of injured spouse/ } \\
\text { partner }\end{array}$} & $26-30$ years & 2 \\
\hline & $31-35$ years & 2 \\
\hline \multirow{4}{*}{$\begin{array}{lll}- & \cdots \\
-\cdots & \end{array}$} & $36-40$ years & 2 \\
\hline & 41-45 years & 4 \\
\hline & $46-50$ years & 2 \\
\hline & $50+$ years & 2 \\
\hline \multirow{5}{*}{$\begin{array}{ll} & \text { Number of children } \\
\therefore & \end{array}$} & 0 & 1 \\
\hline & 1 & 1 \\
\hline & 2 & 6 \\
\hline & 3 & 3 \\
\hline & $4+$ & 3 \\
\hline \multirow[t]{4}{*}{ Time since injury } & 5-8 months & 6 \\
\hline & 9-12 months & 3 \\
\hline & $1-5$ years & 2 \\
\hline & $5-10$ years & 3 \\
\hline
\end{tabular}

The following sections were thus included:

Demographic Information: This section was aimed at obtaining biographic information about subjects and their spouses/partners. Questions regarding the ages of subjects and their partners/spouses, time since the injury, number of children, and duration of marriage/living together appeared in this section. It was felt that time since the injury implied recovery and should therefore be considered in comparison of results. An additional reason for the inclusion of this factor is that marital functioning has been found to deteriorate with increased time since injury (Livingston et al., 1985). Duration of marriagelliving together may indicate stability, which .would affect the adjustment of spouse/partner to injury.

Communication: The onset of a major communication disorder in a married adult frequently has a profound effect on the spouse/partner and the couple's relationship (Rollin, 1988). As such, a section of the questionnaire was dedicated to communication and incorporated a checklist of dysfunctional linguistic patterns found after TBI including vague, tangential language, word finding difficulties and problems experienced in distracting environments (Snow \& Ponsford, 1995). These deficits comprised some of the items on the checklist comparing patients' premorbid and postmorbid communication patterns. Efforts were made to use terms that could be easily understood by lay persons; however, it is still possible that subjects may have assigned different interpretations to those intended. Severity of language dysfunction was not assessed; nor were subjects asked to indicate which communication impairments they regarded as most or least important. Question 1 elicited details regarding the speech of the injured person since speech problems resulting from a traumatic brain injury may contribute to decreased quality of communication (Ponsford, 1995a). Question 2 dealt with the communicative burden placed on the uninjured spouse/partner and question 3 with the sensitivity of the person with TBI to interlocutors in general. An open-ended question was asked regarding the overall effects of altered communication patterns on the relationship in order to elicit individual expression of feelings. 
Occupation and Finance: Financial strain has been documented as a consequence of traumatic brain injury. TBI has also been found to have an adverse, long-term impact on employment and productivity (Hall et al., 1994). Thus, questions in this section dealt with past and present occupational status of both the injured spouse/partner and the subject. In addition, since financial concerns tend to affect quality of life (Bowling, 1995), subjects were asked to compare their premorbid with their present income and standard of living.

Family Life: Following brain injury, there is likely to be a significant disruption of premorbid roles and relationships within the immediate family as well as with parents-in-law (Ponsford, 1995b). Consequently, this section explored the relationship between subjects and their spouse/partner's family; the family's reactions to the individual with TBI; familial visits; the distancing or bonding effects of the injury as well as the changed responsibilities. In addition, subjects were asked to rate their spouses/partners on a five point scale according to their abilities to perform various activities of daily living since functional recovery of patients has been related to family adjustment (McKinlay et al., 1981).

Marital Relationship: Evidence in support of the stresses placed on marital relationships by traumatic brain injury comes from the figures for divorce after brain injury: Seven of the nine severely brain injured married patients, whom Thomsen (1984) followed up ten-to-fifteen years post-injury, had been divorced. Questions in this section were based on factors found by previous studies (such as Panting \& Merry, 1972) to affect marital relationships. Areas that were assessed included: the frequency of arguments since the injury, acceptance of the spouse/partner's limits, consideration of divorce, satisfaction with the marriage, ability of the spouse/partner to fulfil the subjects' emotional needs and the strength of the marital relationship.

Emotional Aspects: In this section spouses/partners were asked about their personalities prior to the injury since the past illness experience, whether psychiatric or médical, of relatives of persons who have suffered brain injury has been found to be highly predictive of their psychosocial breakdown. Many of the deficits associated with brain injury preclude individuals' functioning and self-sufficiency, making! them dependent on family members for financial support, transport and decisionmaking. Lack of independence often places a burden on family members and interferes with their quality of life (Livingston, 1987). Thus, two questions assessed the dependence of injured spouses/partners on subjects and the effects thereof. Subjects were also asked whether their own health had suffered as a result of the injury, since physical health has been implicated as a contributor to a good quality of life (Bowling, 1995). Readjustment of the spouse's/partner's personal schedule is often necessitated by TBI to allow for the assumption of new responsibilities or caring for the injured person and may detract from the quality of life of the subject. Thus, a question regarding the cancellation of personal plans was included at the end of this section.

Social Life: Loss of friends and social isolation are commonly associated with chronic illness or disability and may impact on quality of life (Bowling, 1995). For this reason, questions assessing social isolation and interaction, as well as satisfaction with social life were included.

Coping Resources: Resources such as support groups, case management, medication, recreational activities and respite care have been proposed as potential avenues to relieve the burden of family members and improve quality of life (Hall et al, 1994). The extent to which these factors had been of assistance to subjects in coping with the stresses of the injury was tapped in this section. Responses were considered important since it was anticipated that they would provide practical suggestions for improving quality of life, which was one of the aims of the study.

\section{PROCEDURE}

\section{Pre-testing the questionnaire}

As mentioned previously, the research instrument was based on an extensive literature review and early drafts were scrutinized by an expert in the field of TBI (de Picciotto, 2000) in order to enhance content validity. Efforts to improve the reliability of the questionnaire included consultation with a statistician known to have extensive experience in questionnaire construction, as well as pre-testing the research tool on a subject who met the subject selection criteria but was not included in the final study. These procedures were designed to assess applicability and practicality of questions. Following the pre-test, ambiguous questions were adjusted and the items finely tuned.

\section{DATA COLLECTION}

Upon subjects' agreement to participate in the study, arrangements were made for them to receive, complete and return the hand delivered questionnaire. An Information Sheet set out in Appendix A, explained the purpose of the research project, assured subjects that their anonymity would be respected, provided a contact name and telephone number in the event of the person having any queries, and included a commitment by the researchers to report back the results of the study to participating subjects.

\section{DATA ANALYSIS}

Data were analysed using descriptive statistics in the form of frequency counts and percentages illustrated via a variety of tables and figures.

\section{RESULTS AND DISCUSSION}

Results are presented in accordance with the sub-aims of the study.

\section{PERCEPTIONS REGARDING THE COMMUNICATIVE ABILITIES OF THE INDIVIDUAL WITH TBI}

Figure 1 depicts the distribution of language problems that were reported by the sample.

As evident from Figure 1, disorganized, rambling, tangential language was reported by 9 of the 14subjects. Ylvisaker and Szekeres (1996) suggest that rambling discourse may result from the impaired executive functioning, attentional processes and organizational skills that are characteristic of prefrontal injury. Since 
many of the language patterns associated with TBI have been linked to underlying cognitive dysfunction, it has been suggested that speech-language therapists work within a cognitive-communicative framework of intervention (Ylvisaker \& Szekeres, 1996). Moreover, spouses/partners should be informed about the basis for the communicative difficulties which invariably disrupt conversation and hence, interpersonal relationships, in order to assist their coming to terms with the frustration experienced when conversing with their apparently insensitive partners.

Deficits in selective attention (Snow \& Ponsford, 1995), as well as a difficulty with the figure-ground processing of salient auditory information may have been responsible for the perception of 9 out of 14 subjects, that their injured spouses/partners experienced problems communicating in environments that were full of distractions. One may speculate that this limitation probably affected the subjects' quality of life since it implied a reduced number of locations in which meaningful social or communicative interactions might take place. In places where it is impractical to manipulate the environment in order to facilitate conversation with the injured person, spouses/partners may be forced to avoid communication completely, thereby limiting opportunities for social interaction in the outside world.

Fig. 1 Changes in language patterns as perceived by the spouses/partners of individuals with TBI post-injury (N=14)

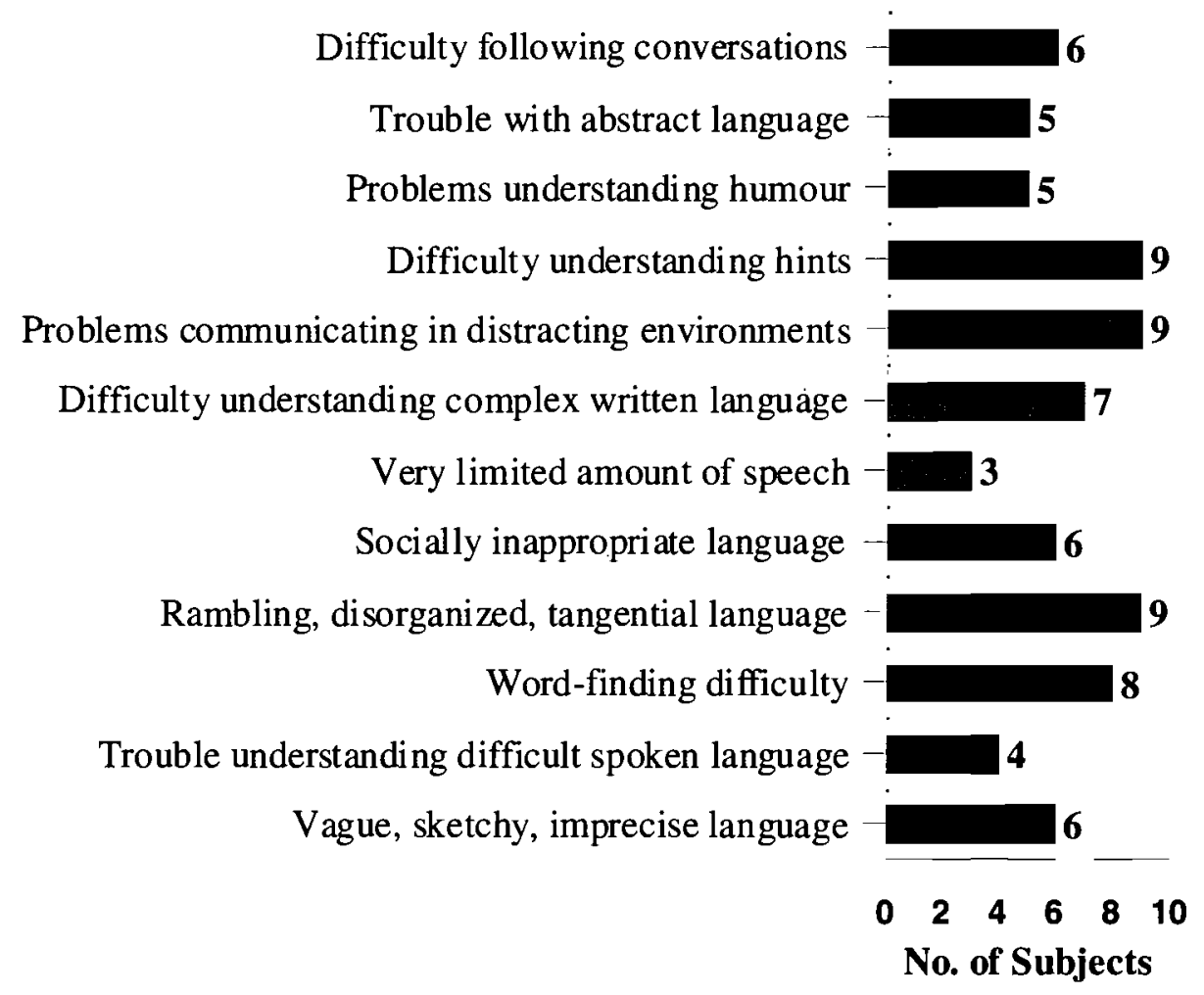

Of the 14 subjects, 9 noted that their injured spouses/partners had difficulty understanding hints. This problem might have resulted from deficits in reasoning ability, which has been defined by Ylvisaker and Szkeres (1996, p.549) as "the process of considering evidence and making inferences or drawing conclusions". The

- inability to understand hints may lead to frustration of spouses/partners at having to spell out all their requests directly. Conveying information directly may not always be appropriate such as when speaking in front of children or in company. In addition, when the subtleties of sexual innuendo are not understood, deterioration in intimate relationships may result (Ylvesaker \& Szekeres, 1996).

Word finding difficulty, which 8 out of 14 subjects reported, was also documented by Thomsen (1975) as one of the more common linguistic problem following head injury. When the speaker has word retrieval difficulties, there may be an increased burden on the interlocutor, such that he/she must guess the intended words, encourage circumlocution or endure the frustration and helplessness of seeing the speaker struggling to express him/herself.

Six subjects reported vague, sketchy and imprecise language, which may have been caused by listener insensitivity or word retrieval problems. It is likely that this linguistic pattern may be a source of frustration for the interlocutor who may experience difficulty comprehending the injured person's message.

Six of the 14 subjects characterized the language of their injured spouses/partners as being socially 
inappropriate. Indeed, inattention to social context resulting in socially inappropriate behaviour and verbal 'dysdecorum' has been described as associated with prefrontal damage (Alexander, Benson \& Stuss, 1989). For example, one subject commented, "When in company, his communication is totally unacceptable. The things he says embarrasses everyone, including me." Withdrawal from social situations and public gatherings may result from such embarrassment. Spouses/partners may also have to endure verbal abuse, which might decrease their self-esteem and quality of life.

Of the 14 subjects, 6 perceived that their spouses/partners had difficulty following conversations; whilst 4 reported that their spouses/partners had trouble understanding difficult spoken language. Presumably, such deficits might manifest in a loss of interest of injured persons when their spouses/partners attempt to discuss problems of daily living or issues in their relationship. Thus the quality and quantity of interaction could be adversely affected.

Five out of the 14 subjects noted that their injured spouses/partners had problems understanding humour. Comprehension of humour has been attributed to the ability to think abstractly, a capacity that is frequently damaged as a result of brain injury (Hartley, 1995). If one member of a couple cannot appreciate humour, their relationship may lack a means by which to release tension in order to alleviate the gravity of the situation.

When asked to elaborate on their spouse/partner's communication problems in response to the open-ended item, subjects mentioned lack of eye contact, motor speech difficulties, and speech that was either too soft, too slow or dysfluent. In addition, eight subjects reported that they sometimes found communication with their partners/spouses to be tiring. Whilst four noted that communication was often tiring, only one subject reported never finding communication tiring. The fact that all but one subject found communication with their spouses/partners to be tiring seemed to highlight the communicative burden placed on the interlocutor by ińjury-related communication problems. This result may indicate use of ineffective communication techniques, a problem that perhaps should receive more prominence as an intervention goal of speech-language therapists. The concentration required to guess the message of the person with TBI as well as the effort required to explain or rephrase to ensure the comprehension of an injured spouse/partner might induce fatigue or despair. As a result, spouses/partners might refrain from discussing their concerns with the individual with TBI, causing emotional burdens and stress to accumulate, not having had an opportunity to be expressed. Persons with TBI, too, might be given fewer opportunities to express their own problems, causing frustration and aggression. The egocentricity (Lezak, 1988), rigidity and lack of insight (Giles \& Clark-Wilson, 1993) that have been reported as sequelae of brain injury, might cause individuals with brain injury to demonstrate an inability to adapt to their conversational partners. In the current study, perceptions of the injured spouses/partners' sensitivity to the listener were gauged with reference to these particular manifestations. Eight subjects reported that their spouses/partners rephrased, explained or repeated information when the listener failed to understand them. However, 6 injured persons were reported not to demonstrate such sensitivity. In addition, 10 out of the 13 individuals who answered the question reported that their spouse/partners tended to overestimate or underestimate the listener's knowledge of the subject being discussed. As may have been expected, given the above-mentioned results indicating decreased listener sensitivity, all but 2 subjects reported that communication tended to break down between themselves and their spouses/partners. Of these, half reported that breakdown occurred often; whilst the other half noted that breakdown only occurred sometimes. Frequent conversational breakdown may cause a great deal of frustration and resentment to the communicatively impaired individual, who is often unaware of his/her deficits (Snow \& Ponsford, 1995), as well as for the interlocutor.

Twelve of the 14 subjects reported that their injured spouses/partners with TBI often misinterpreted what they had said to them. If frequent breakdown or misinterpretation of communication is used as a measure of quality of life, then brain injury with its effects on communication may be said to have detracted from the quality of life of 12 of the 14 spouses/partners.

Many relationship breakdowns have been attributed to faulty communication, even without the added burden of a neurogenic communication disorder (LaPointe, 1999). In the face of the many expressive and receptive language difficulties that have been associated with traumatic brain injury, relationships are even more likely to be at risk. Nine out of the 14 subjects in the current study affirmed that their spouse/partners' altered communication had affected their relationship in some way. Verbatim quotes set out in Table 4 starkly reflect the impact on sexual relationships, communication, roles and personality.

In summary, a wide variety of communicative impairments were found to have detracted from the quality of life of most subjects in the current study, and appeared to suggest the need for speech-language therapists to assist couples to find more effective ways of communicating.

\section{IMPACT OF INJURY ON THE OCCUPATIONAL STATUS OF THE PERSON WITH TBI AND THE FINANCIAL STATUS OF SPOUSES/PARTNERS.}

The current study found that of the 14 brain injured persons who were reported by their spouses/partners to have been employed full-time prior to the injury, 10 had not returned to work at all, 2 worked part-time, 1 ran errands for his spouse at work, and 1 was employed in a different capacity. These results are in line with the research literature which confirms that TBI often results in cognitive, physical, psychological or communicative deficits, which may preclude the injured person's return to work. Return to work statistics range from $3 \%$ to $100 \%$ depending on the severity and sequelae of the injury, the demands of the job as well as a multitude of other factors (Penn et al., 1998).

Furthermore, economic issues relating to medical treatment, rehabilitation, earnings loss and caregiver role adjustment may create enormous concerns for individuals and families in health care crises (LaPointe, 1999). In the current study, 9 subjects indicated that their income had dropped significantly since the injury, 2 stated that their income had dropped slightly while only 3 subjects 
commented that their income had remained the same as it had been prior to the injury. These findings suggest that in the majority of cases, TBI had impacted on quality of life.

The World Health Organization (1993) related quality of life to the individual's perceptions of his/her position in life in relation to his/her goals, standards and expectations. As such, satisfaction with standard of living may be said to impact extensively on perceived quality of life. In the current study, the number of subjects who expressed satisfaction with present standards of living compared to pre-injury standards was equal to the number of subjects who expressed dissatisfaction. This finding seemed to indicate spouses/partners' adjustment and adaptation to the decreased financial status as a consequence of brain injury on the part of those subjects who reported feelings of satisfaction with living standards. However, a weakness of the research project was that self-administered questionnaires did not facilitate further probing of individual items.

\section{CHANGES IN FAMILY DYNAMICS, ROLES AND RESPONSIBILITIES:}

The majority i.e. 13 of the 14 subjects affirmed that there had been a change in their family relationships since their spouse/partner's injury. This finding is in accordance with family systems theory, which views the family as a homeostatic entity where each unit is dependent on every other. As such, a traumatic brain injury sustained by one member is likely to cause a disturbance in the equilibrium of the entire family.

Upon analysis of the comments of participants regarding changes in their family relationships, deterioration of relationships with children emerged as a common theme. Examples of subjects' comments regarding the effects of the injury on children may be seen in Table 2.

Table 2: Perceived effects of injury on children $(\mathrm{N}=11)$

\begin{tabular}{|c|c|}
\hline Themes & Quotes \\
\hline Children's fear of parent with TBI & $\begin{array}{l}\text { - He has very little patience with } \\
\text { children and they have become wary of him, } \\
\text { sometimes even scared. } \\
\text { - Children are too scared to talk to him } \\
\text { because he does not understand when they are } \\
\text { joking and when they are serious. } \\
\text { - Most of the children (mine) are } \\
\text { nervous of him. }\end{array}$ \\
\hline Injured parent's reaction to children & $\begin{array}{l}\text { - He has very little patience with } \\
\text { children. } \\
\text { - Lost his love and relationship with } \\
\text { children. Very formal and irritable with } \\
\text { children. } \\
\text { - Takes very little interest in the } \\
\text { children. }\end{array}$ \\
\hline Roles/responsibilities of children & $\begin{array}{l}\text { Elder son grew up quickly - } \\
\text { emotionally played father roles. } \\
\text { - New roles had to be filled by children. They } \\
\text { are not as carefree as other kids. } \\
\text { - Due to decreased finances had to let maid go, } \\
\text { so children have to help around house. }\end{array}$ \\
\hline
\end{tabular}

The loss of a child's relationship with one parent may have the impact of draining the emotional resources of the uninjured parent. The latter might feel it necessary to devote more attention, time and love to the child at the expense of his or her own needs and quality of life. Consequently, counselling of children and parents may ease the burden that the changes in family dynamics have imposed.

In the current study, 13 of the 14 subjects expressed the view that their relationships with their spouse/partner's family had changed since the injury. In general, the injury was perceived by 6 subjects to have brought family members closer. Three subjects did not perceive any effect on family cohesion. However, 4 subjects stated that the injury had caused negative changes in the form of friction and decreased support and had estranged family members. Mauss-Clum and Ryan
(1981) pointed out that there tended to be conflict between the uninjured spouse and his or her in-laws. They explained that parents might see their role as protecting their child from the possibility of divorce and were likely to become possessive and jealous. Decreased contact with immediate and extended family members might also have resulted from friction caused by reversal of roles or the family's discomfort with behavioural, communicative or cognitive changes. In this respect, Rosin (1977) noted disengagement to be a method of dealing with the brain injury of a relative. In the process, family and friends might be neglected due to lack of time following the spouses/partners' assumption of additional responsibilities (Boisclair-Papillon, 1993). Friends might also feel uncomfortable or awkward in the presence of the brain-injured person and decrease their contact with the spouse/partner too as a result. 
However, although infrequent visiting and avoidance of the injured person might help the extended family to adjust to the effects of the injury, spouses/partners of the injured person may experience isolation and a lack of support due to the reduction in family contact. It is of interest that 8 subjects in the present study reported that the extended family, including aunts, uncles and cousins, tended to visit as often as they did before the injury. Likewise, 7 subjects mentioned that the immediate family tended to visit as frequently as previously, while one subject reported that visits were more frequent following the injury. Frequent visiting may indicate the presence of family support and adjustment to the injury. In order to foster increased understanding, spouses/partners should be provided with the emotional support as well as the information needed to explain the consequences of the injury to the injured person's family.

In order to gain a better understanding of the extent to which roles had shifted since the injury, the current study required subjects to indicate the person responsible for various tasks before and after the injury.

Table 3: Responsibility for various tasks pre and post-injury

\begin{tabular}{|l|l|l|l|l|l|l|}
\hline Task & \multicolumn{3}{|l|}{ Pre-injury } & Post-injury & \multicolumn{2}{l|}{} \\
\hline & Self & $\begin{array}{l}\text { Spouse/ } \\
\text { partner with } \\
\text { TBI }\end{array}$ & Both & Self & $\begin{array}{l}\text { Spouse/ } \\
\text { partner with } \\
\text { TBI }\end{array}$ & Both \\
\hline $\begin{array}{l}\text { Caring for } \\
\text { children (n=8) }\end{array}$ & 5 & 2 & 1 & 7 & 0 & 1 \\
\hline $\begin{array}{l}\text { Dealing with } \\
\text { medical aid \& } \\
\text { social agencies } \\
\text { (n=10) }\end{array}$ & 5 & 4 & 1 & 10 & 0 & 0 \\
\hline $\begin{array}{l}\text { Running } \\
\text { household } \\
\text { (n=10) }\end{array}$ & 6 & 2 & 2 & 9 & 0 & 1 \\
\hline $\begin{array}{l}\text { Making } \\
\text { financial } \\
\text { decisions (n=10) }\end{array}$ & 1 & 5 & 4 & 9 & 1 & 0 \\
\hline $\begin{array}{l}\text { Providing main } \\
\text { source of } \\
\text { income (n=10) }\end{array}$ & 3 & 4 & 3 & 7 & 3 & 0 \\
\hline
\end{tabular}

Numbers in the different categories do not total 14 as not all tasks were applicable to all subjects.

Table 3 shows that where the responsibility of caring for children had previously been that of the spouse/partner who had sustained the injury, it was now shared and where it had been a shared duty, the role had been assumed by the uninjured spouse/partner. The relinquishment by many of the injured persons of tasks such as dealing with medical aid and social agencies, running the household, making financial decisions, and being the main source of income, is understandable if one considers that injury to the frontal lobes of the brain tends to impair executive functioning including planning, problem solving, judgement and decision-making (Ponsford, 1995a).

Upon analysis of the reactions of subjects to role changes, most appeared to have accepted their additional responsibilities. Only two subjects admitted to feeling angry or uncertain as a result of having to undertake new responsibilities. Others appeared to acknowledge the difficulties, yet expressed acceptance of their lot. These results provide support for the literature which states that role reversal may impact extensively on the quality of life of the uninjured spouses/partners upon whom additional new roles and responsibilities are suddenly thrust (LaPointe, 1999).

\section{PERCEIVED INFLUENCE OF INJURY ON MARITAL/COMMON LAW RELATIONSHIPS:}

Table 4 shows the subjects' extent of agreement or disagreement with various statements regarding the perceived influence of the injury on marital or common law relationships.

Half of the current sample reported that their relationship with their spouse/partner had deteriorated with the passage of time since the injury. However, although the small number of subjects precluded the computing of correlations, the time since injury did not appear to affect perceptions of marital decline. Deterioration in marital relationships was noted by those whose spouses/partners had sustained the injury 5-10 years before as well as by those who had been injured between 5-12 months previously. However, 6 other subjects whose spouses/partners' injury had occurred between 1-5 years before as well as 5-8 months before, failed to report such a decline. In terms of the literature, marital functioning was noted to have decreased between 3 and 6 months post-injury in a study by Livingston, Brooks and Bond (1985).

Duration of marriage also did not appear to influence the perception of marital decline over time as couples who had been married for 1 year, 6 years, 25 years and 28 years reported decline, while others with marriages of 7,16 and 34 years duration failed to report deterioration. Nevertheless, since half the subjects reported that they perceived their marriages to have deteriorated over time, referrals for marital counselling, guidance regarding future expectations, and long-term coping strategies may 
need to be made available in an effort to conserve marriages and increase the quality of life of both partners.

In the current study, 5 of the 7 subjects noted that their injured spouse/partner had become more aggressive and also reported more arguments since the injury. Increased aggression and irritability are commonly reported personality changes following brain injury (Giles and Clark-Wilson, 1993) and might lead to an increase in arguments. Eight subjects stated that they had not considered divorce. Lezak (1988) explains that feelings of responsibility, past gratitude to the spouse, guilt, and fears of social rejection might make it difficult to initiate separation or divorce procedures. Results from the present study may also indicate that subjects had resigned themselves to their new roles, having managed to accept and adjust to changes in their spouses/partners. Indeed, 10 subjects admitted that they had accepted their spouses/partners' limits. In addition, the possibility of subjects furnishing 'socially desirable' responses to these very sensitive items cannot be discounted, and leaves the validity of this item open to question (Rosnow \& Rosenthal, 1996). It is also possible that it was too early post-injury for respondents to assess the long-term effects of the injury on the marital relationship.

Table 4: Perceived influence of injury on marital/common law relationship

\begin{tabular}{|l|l|l|l|}
\hline \multicolumn{1}{|c|}{ Statement } & \multicolumn{1}{c|}{$\begin{array}{c}\text { Strongly } \\
\text { Agree/agree }\end{array}$} & \multicolumn{1}{c|}{$\begin{array}{c}\text { Disagree/ } \\
\text { Neutral }\end{array}$} & Strongly Disagree \\
\hline $\begin{array}{l}\text { Our marital relationship has not changed } \\
\text { despite the injury }\end{array}$ & 10 & 1 & 3 \\
\hline $\begin{array}{l}\text { My relationship with my souse/partner } \\
\text { has deteriorated as time has passed since } \\
\text { the injury }\end{array}$ & 7 & 1 & 6 \\
\hline I accept my spouse/partner's limits & 10 & 2 & 2 \\
\hline I have considered divorce & 3 & No response & 8 \\
\hline $\begin{array}{l}\text { I feel as though I am married to a } \\
\text { stranger since the injury }\end{array}$ & 7 & 5 & 2 \\
\hline $\begin{array}{l}\text { I have a close, confiding relationship } \\
\text { with my spouse/partner }\end{array}$ & 4 & 4 & 6 \\
\hline I keep my frustration inside myself & 11 & 1 & 2 \\
\hline I am satisfied with my marriage & 5 & 2 & 7 \\
\hline $\begin{array}{l}\text { My spouse/partner can no longer fulfill } \\
\text { my emotional needs adequately }\end{array}$ & 10 & 3 & 1 \\
\hline $\begin{array}{l}\text { We argue more now than we did before } \\
\text { the injury }\end{array}$ & 7 & 3 & 7 \\
\hline
\end{tabular}

Note: Responses from the 5-point rating scale were collapsed to form three categories. $N=14$

Eleven subjects reported that they tended to keep their frustration inside themselves. The effect of a build-up of inner frustration has been shown to exert an adverse effect on people's physical and mental health (Burnard, 1991). Hence, rehabilitation personnel should be made aware that spouses/partners might appear from the outside to be coping with their roles and their spouse/partner's deficits. However, internally, they might harbour much anxiety and frustration that needs to be expressed and addressed.

Half of the subjects in the current study agreed with the statement "I feel as though I am married to a stranger since the injury". In this respect, the personality change that results from brain injury has been reported to be most difficult for spouses/partners to deal with (McKinlay et al., 1981; Thomsen, 1984) presumably since it alters the dynamics and fulfilment of needs - within the relationship. The high number of neutral or uncertain replies to this item may have been due to a 'central tendency response set' whereby subjects tend to choose the central response options rather than committing themselves to a definite agree or disagree response

Only 6 of the 14 subjects reported not having a close, confiding relationship with their injured spouse/partner. The fact that so few relationships were said to be close and confiding might indicate the need for marriage counselling of persons with TBI and their spouses/partners.

Ten subjects in the current study reported that their injured spouses/partners were unable to fulfil their emotional needs adequately. This phenomenon may be explained by the fact that because brain injured spouses/partners often tend to be childish, self-centred and irritable, they are unable to provide the emotional support that had formed an integral part of their relationships prior to the injury (Mauss-Clum \& Ryan, 1981). According to Lezak (1988), spouses may suffer the loss of a relationship that satisfies even the most basic expectations of a marriage.

One subject in the present study remarked that her husband who used to be her "best friend and lover" had now become no more than a "child-like companion." Half of the subjects in the current sample asserted that they were not satisfied with their marriagés, probably indicating a perceived reduced quality of life. However, 5 subjects expressed marital satisfaction despite the injury, suggesting positive adjustment as well as a satisfactory quality of life. It is also possible that the 'central tendency response set' was operating, whereby subjects responded similarly to various items (Rosnow \& Rosenthal, 1996). 
Subjects were asked to describe changes in the spouse/partner post-injury which had exerted the most impact on the relationship. Analysis of the verbatim responses of subjects revealed certain common themes which are highlighted in Table 5.

Table 5: Changes in spouse/partner with TBI that had exerted the most impact on the marital/common-law relationship ( $\mathbf{N}=11)$

\begin{tabular}{|c|c|}
\hline Themes & Quotes \\
\hline Loss of sexual relationship & $\begin{array}{l}\text { - He is constantly insecure because we do not } \\
\text { have an intimate sex life. His brain cannot } \\
\text { function in that way yet. I accept that. I have } \\
\text { become very sympathetic. } \\
\text { - I have lost my best friend and lover. We don't } \\
\text { have fun anymore. We don't have sex } \\
\text { anymore and I am very wary of confiding in } \\
\text { him. } \\
\text { - No love life. } \\
\text { Between him and myself, he is just the } \\
\text { patient and I am the caregiver / provider } \\
\text { /decision-maker. There is no other aspect to } \\
\text { the relationship. }\end{array}$ \\
\hline Communication changes & $\begin{array}{l}\text { - No communication } \\
\text { - We also can't communicate as well as we } \\
\text { used to. }\end{array}$ \\
\hline $\begin{array}{l}\text { Personality changes: blunted emotion, increased } \\
\text { aggression }\end{array}$ & $\begin{array}{l}\text { - Lack of emotion; increased aggression; onset } \\
\text { of depression / negativism } \\
\text { - His changed personality. He is quite } \\
\text { aggressive now and it's like living on the } \\
\text { edge of a volcano. } \\
\text { - He is a different person. His personality has } \\
\text { changed. } \\
\text { - He is also very unemotional in positive } \\
\text { loving ways. } \\
\text { - He was also a very loving, touchy person. } \\
\text { This has all gone. Not only did we live } \\
\text { together, play together etc., we also worked } \\
\text { together in the same company, different } \\
\text { departments. } \\
\text { Loss of intellectual ability and confidence }\end{array}$ \\
\hline Role change & $\begin{array}{l}\text { - I have become the senior partner in } \\
\text { running things which he is too proud to } \\
\text { feel comfortable with. } \\
\text { - The fact that he is not able to help with } \\
\text { fetching and carrying of kids. } \\
\text { - Changes in roles. }\end{array}$ \\
\hline Separation & $\begin{array}{l}\text { - The fact that he had been in and out of } \\
\text { hospital has had a dramatic impact on our } \\
\text { relationship. }\end{array}$ \\
\hline
\end{tabular}

The profound effect of traumatic brain injury on the marital relationship is reflected in the statement by one of the subjects:. "Between him and myself, he is just the patient and I am the caregiver/provider/ decision-maker. There is no other aspect to the relationship." Many subjects mentioned the loss of the sexual relationship. Communication changes and role shifts were also reported to have affected the marital relationship as well as personality changes, particularly blunted emotion. These results appear to be in line with the findings of Tate et al. (1989) who conducted a follow-up study six years post-injury, and found that marital breakdown had occurred in $63 \%$ of marriages in the group of brain injured persons with moderate to severe brain injury and in $42 \%$ of those with good outcomes.

\section{PERCEIVED EMOTIONAL EFFECTS OF INJURY ON SPOUSE/PARTNER:}

The occurrence of traumatic brain injury creates an immediate crisis for relatives, disrupting established relationships, roles, expectations and goals within the family unit (Ponsford, 1995b). However, the crisis is often ongoing since character changes, altered communication patterns and cognitive limitations tend to be of a permanent nature. The advent of brain injury may 
be said to mark the beginning of the spouse/partner's ride on an emotional roller-coaster.

Eight subjects in the current study appeared to deny the permanence of their spouse/partner's disability by reporting that they lived with the hope that their spouse/partner would wake up and return to his/her preinjury self. The remaining 6 subjects did not appear to have such unrealistic expectations. However, one stated that she expected her spouse/partner to recover slowly. Based on extensive contact with 13 families of severely head injured patients, Romano (1974) observed denial to be a powerful tool used to come to terms with sudden disability, one of the manifestations of which was the tendency towards fantasies. The tendency towards unrealistic expectations must be considered by rehabilitation personnel when working with spouses/partners, who might resist attempts at the rehabilitation of the injured person (Ponsford, 1995b) or even blame therapists for the failure of the person to return to premorbid capabilities.

Livingston (1987) found that the post-injury adjustment of relatives correlated with their previous psychiatric and medical history. Spouses/partners were thus asked to describe their personalities before the injury. Ten subjects considered themselves to have been independent, and 9 said that they had been easy-going. These traits probably assisted greatly in the assumption of new responsibilities following the injury. Eleven considered themselves sociable, perhaps implying a large framework of social support, or perhaps frustration in the event of social isolation.

In terms of their reactions to their relative's disabilities, Lezak (1988) pointed out the potential of relatives to become deeply conflicted between feelings of responsibility, anger and frustration, and hope for the recovery of the injured person, making them prone to depression. The emotional devastation felt by one of the subjects in the current study was poignantly expressed in the following statement: "All the changes in my husband have frightened and shocked me. I find myself lying about how things are just to keep the peace - somewhere in this mess I lost me!" Current findings showed neither anger nor irritability to be very prevalent, with only 5 out of the 12 subjects reporting these emotional reactions following the injury. Sadness was reported by ten subjects and the same number noted that their spouse/partner's disability had caused them to feel burnt out, possibly as a result of role overload. Eleven of the 12 subjects who responded to this item in the current study noted that they felt frustrated as a result of their spouse/partner's disabilities and one subject reported feeling helpless. Consequently, it is important that rehabilitation personnel and counsellors advise spouses/partners that negative emotions tend to be a natural consequence of disruption to life and marital relationships.

Notwithstanding the prevalence of negative emotions, feelings of acceptance were noted by 11 subjects in the current study, as was the case in relation to role changes explored in the third sub-aim. It is possible that subjects might have accepted the presence of disability intellectually. Yet, in reality, on an emotional level, they may have experienced conflict and burdens resulting in frustration, anger and irritability. Since anguish, fatigue and depression drain the spouse/partner of availability, patience and inventiveness, counselling of the spouse/partner is likely to have a positive effect on both the injured person as well as the entire family.

The dependence of injured persons on their spouses/partners for activities of daily living may impact on the spouses/partners' perceived quality of life. Indeed, 6 subjects in the current study noted that they felt tied down to a great extent by their spouse/partners' dependence on them. Another 6 stated that dependence caused them to feel somewhat lacking in independence. Only 2 subjects commented that they did not feel tied down at all despite their spouses/partners' dependence.

In terms of dependence/ independence, several factors were considered, namely, transport, decision-making, finance, and communication with unfamiliar people. Results are reflected in Table 6 . The finding that only 3 spouses/partners were completely independent in relation to transport, was not surprising considering that only one subject reported that her/his spouse/partner was able to drive well. However, in hindsight, it would seem that the terms describing driving ability were not adequately defined, for example, did average driving ability imply ability to drive independently? A further shortcoming of the study was that aspects such as decision-making and finances were not probed further.

Table 6: Extent of dependence of injured spouse/partner on respondents $(N=4)$

\begin{tabular}{|c|c|c|c|}
\hline Factors & Totally Dependent & Partially Dependent & $\begin{array}{c}\text { Completely } \\
\text { Independent }\end{array}$ \\
\hline Transport & 6 & 5 & 3 \\
\hline Decision-making & 9 & 5 & 0 \\
\hline Finances & 10 & 3 & 0 \\
\hline $\begin{array}{c}\text { Communication with } \\
\text { unfamiliar people }\end{array}$ & 8 & 4 & 2 \\
\hline
\end{tabular}

The effects of having to care for a spouse/partner as a parent cares for a child may increase the resentment and difficulties involved in care giving. Provision of practical advice to increase the spouse/partner's perceptions of freedom might assist them to cope better both psychologically and physically. By hiring a driver, the person with TBI might become independent in terms of transport. Referral to a financial consultant for financial counselling and advice might assist the uninjured spouse/partner to meet the challenge of financial planning and decision-making with more confidence and skill. Speech-language therapy might equip the person with $\mathrm{TBI}$ to regain independence in the domain of communication.

Ten out of the 14 subjects reported that their physical health had suffered in some way as a result of the stress of their partner/spouse's brain injury. This result is not surprising since family members tend to put 
aside their own interests and needs to give maximal support to the injured person. Such sacrifice cannot be sustained without a significant physical or emotional toll (Ponsford, 1995b). It is therefore critical that spouses/partners be cautioned by rehabilitation workers to take time out for themselves to maintain their efficiency as caregivers and their quality of life.

The postponement or cancellation of personal plans as a result of their spouse/partners' injury was reported by 11 of the 14 subjects in the current study. Ironically, many of the uninjured subjects experienced a degree of handicap, being unable to conduct their lives in accordance with their desired plans. However, whether they resented this postponement or merely accepted it as a fact, is open to speculation. According to LaPointe (1999), health care professionals may fail to recognize the magnitude of the challenge of compromise that is involved in adapting to the new demands that necessitate a change of lifestyle. Perceptions of a disappointing quality of life might cause the build-up of frustration and resentment, which might be expressed as anger towards the injured person or inadequate fulfilment of responsibilities. Rehabilitation personnel and other family members should thus encourage the spouse/partner to accomplish their personal plans where possible and to develop their own interests. In addition, counselling of spouses/partners by therapists or psychologists should be encouraged in order to help them to express and work through the emotional and psychological impact of the injury.

\section{INFLUENCE OF SOCIAL ASPECTS ON QUALITY OF LIFE}

Table 7 illustrates the effects of the injury on subjects' social life. With regard to the loss of friends, it is not clear how long after the TBI this loss occurred and needs to be researched in greater depth than allowed by the current study. Although socially inappropriate language was only reported by 6 subjects (as discussed under the first sub-aim), 7 subjects noted that they experienced discomfort in social situations since their spouses/partners tended to say the wrong things at the wrong times. This finding is understandable if one considers that pragmatic impairment is a major component of language impairment in TBI (Alexander, Benson \& Stuss, 1989). In addition, it was not surprising that 5 subjects mentioned feeling embarrassed as a result of their injured spouse/partner's behaviour in company. Interestingly, however, only 3 subjects admitted that they tended to avoid social contact.

Table 7: Perceived effects of the injury on respondents' social life ( $N=14)$

\begin{tabular}{|c|c|c|}
\hline Statement & Yes & No \\
\hline I often feel lonely. & 11 & 3 \\
\hline $\begin{array}{c}\text { I feel responsible for meeting } \\
\text { the social needs of my } \\
\text { spouse/partner. }\end{array}$ & 11 & 9 \\
\hline $\begin{array}{c}\text { I feel that I have lost many } \\
\text { friends since the injury. }\end{array}$ & 5 & 10 \\
\hline $\begin{array}{c}\text { I have made many new friends } \\
\text { since the injury. }\end{array}$ & 4 & 11 \\
\hline I avoid social contact. \\
$\begin{array}{c}\text { I am embarrassed by my } \\
\text { spouse/partner's behaviour in } \\
\text { company. }\end{array}$ & 5 & 9 \\
\hline $\begin{array}{c}\text { My spouse/partner says the } \\
\text { wrong things at the wrong time } \\
\text { causing me discomfort in social } \\
\text { situations. }\end{array}$ & 7 & 7 \\
\hline
\end{tabular}

The majority of subjects in the current study felt responsible for meeting the social needs of their injured spouses/partners with TBI. By increasing their involvement with the injured person, spouses/partners might have less time to devote to the maintenance of their previous friendships. This finding is in line with the results obtained by Kozloff (1987) who studied 37 persons with severe brain injuries and their families. This researcher found that relatives attempted to compensate for the patients' psychosocial inadequacies by expanding their involvement with the patients themselves. The fact that 11 of the 14 subjects also reported that they frequently experienced feelings of loneliness, could possibly be due to decreased time for social arrangements or estrangement from friends and from the spouse/partner. One subject affirmed this explanation saying "All our friends don't like to mix in as I am now considered a threat (so called)". It is likely that the loss of Die Suid-Afrikaanse Tydskrif vir Kommunikasieafwykings, Vol. 48, 2001 the companionship, guidance and support of a spouse/partner might be the greatest source of loneliness as one subject commented: "I have lost my best friend and lover...I am very wary of confiding in him." Consequently, the fostering of both new and old friendships, as well as membership of support groups should be encouraged on the basis that a larger social circle is likely to ultimately lead to an increase in emotional support and quality of life.

No definitive trends emerged regarding the satisfaction of subjects with their present social life in comparison with their social life before the injury since responses were evenly distributed along the continuum. Six subjects expressed satisfaction with their present social life, 2 remained neutral and 6 others reported dissatisfaction. Nonetheless, rehabilitation personnel should be aware of the potential for decreased social opportunities to impact negatively on spouses/partners' 
quality of life. Where necessary, counselling should be provided to assist individuals to deal with their frustrations. Furthermore, spouses/partners and their families should be encouraged to seek additional opportunities for socialization, particularly, given the broad base of evidence that social support buffers the deleterious effects of stress and anxiety and contributes to psychological well-being (LaPointe, 1999).

\section{EXPLORATION OF COPING MECHANISMS}

Subjects were asked to assess the degree to which certain factors had helped them to cope with the consequences of traumatic brain injury in their spouse/partner. Results are summarized in Table 8.
The finding that 5 subjects had not received any form of psychological counselling suggested under-utilization of such services which could have been due to any number of reasons, including lack of access, the costs involved, as well as the stigma still associated by some people with this type of therapy. This finding also suggested the need for speech-language therapists to incorporate spouse/partner counselling into any therapy programme so that significant others who are not in contact with other professionals, may receive the necessary emotional support. Ideally, psychological counselling provides an opportunity for the spouses/partners of persons with TBI to work through their emotional responses and to raise practical problems (Ponsford, 1995b).

Table 8: Extent of helpfulness of coping resources ( $N=14)$

\begin{tabular}{|c|c|c|c|c|}
\hline Coping Resource & Very helpful & Somewhat helpful & $\begin{array}{c}\text { Not at all } \\
\text { helpful }\end{array}$ & $\begin{array}{c}\text { Not } \\
\text { Applicable }\end{array}$ \\
\hline Psychological counselling & 2 & 5 & 3 & 4 \\
\hline Religion & 8 & 3 & 3 & 0 \\
\hline Support groups & 5 & 2 & 2 & 5 \\
\hline Domestic help & 5 & 6 & 1 & 2 \\
\hline Friends & 10 & 2 & 2 & 0 \\
\hline Medication & 4 & 5 & 3 & 2 \\
\hline
\end{tabular}

The fact that a relatively large proportion of subjects felt that religion had helped them to come to terms with the devastation of TBI, is understandable if one considers that under such conditions, some people may adopt a philosophical outlook, searching life for meaning and exploring the significance of their existence relative to a Higher Being. While half the subjects reported that support groups had been either very helpful or somewhat helpful, it is of concern that 5 persons had either not had access to or had not made use of such services.

Table 9: Coping strategies perceived as most effective ( $N=12)^{*}$

\begin{tabular}{|c|c|}
\hline Themes & Quotes \\
\hline Friends & $\begin{array}{l}\text { - Support and good friends who listened, cooked or spent } \\
\text { time with my husband. } \\
\text { - Caring friends }\end{array}$ \\
\hline Family & $\begin{array}{l}\text { - Family and friends' assistance and support } \\
\text { - My children, sister, brother-in-law } \\
\text { - Plenty of family support and support from my spouse }\end{array}$ \\
\hline Religion & $\begin{array}{l}\text { - Prayer } \\
\text { - Faith in God } \\
\text { - } \text { supportive church } \\
\end{array}$ \\
\hline Medication & - Medication for depression \\
\hline Inner strength & $\begin{array}{l}\text { My strong personality and determination to succeed and } \\
\text { I kept saying to myself * I'll get you, you } * * * * \text { before I } \\
\text { really understood his problem. Then I had to. swim or } \\
\text { sink and I wasn't prepared to sink. I also had to cope } \\
\text { with "another woman" and to accept that also was due to } \\
\text { his injury. } \\
\text { - I am a strong person. }\end{array}$ \\
\hline Other & $\begin{array}{l}\text { - Previous experience } \\
\text { - Having an outside 'care-manager' to co- ordinate } \\
\text { therapies, living skills, medical follow-ups, monitor } \\
\text { 'scientific progress', move to new different levels of } \\
\text { therapy etc. } \\
\text { - Time, love } \\
\text { - Avoiding dealing with it. } \\
\text { - Extremely supportive employer and spouse's colleagues }\end{array}$ \\
\hline
\end{tabular}


* Only 12 respondents answered this question.

Overall, subjects in the current study did not appear to rate domestic help as crucial. However, a limitation of the study is that type and frequency of domestic help was not probed - variables which may have influenced the results of the study. Information was also not sought regarding type of medication or whether medication was taken prior to the spouse/partner experiencing TBI.

Subjects reported that friends contributed most to coping with brain injury. Despite 5 subjects having reported that they had lost many friends since the injury, 10 subjects related stories of having been helped to cope with their crisis to a large extent by friends "who listened, cooked or spent time with my husband to allow me time out". Upon analysis of responses of subjects to a question assessing what had been most effective in helping them deal with the stresses resulting from traumatic brain injury, various common themes were evident, including friends, family, religion, inner strength and medication. Direct quotations reflecting subjects' coping strategies may be seen in Table 9.

Healthcare workers and counsellors should take cognizance of the positive coping strategies demonstrated by the spouses/partners of persons with TBI, in order to reinforce them and encourage their generalization to other difficult situations. It may also be helpful for rehabilitation personnel to attempt to discuss strategies to facilitate the coping of their clients such as recommending that they take vacations, keep a diary, attend inspirational lectures or use relaxation techniques. In addition, spouses/partners should be encouraged to participate in activities that have been found by others to decrease stress in an effort to enhance their perceived quality of life.

\section{SUMMARY OF RESULTS}

The findings in this study showed that a range of factors affected the perceived quality of life of a group of spouses/partners of persons who had sustained traumatic brain injury. Communicative changes were found to have detracted from the quality of life of most subjects in the current study; with the most frequently mentioned dysfunctional linguistic patterns being difficulty understanding hints; problems communicating in distracting environments; rambling, disorganized, tangential language; and word-finding difficulties.

Almost three-quarters of the current sample reported that their injured spouses/partners had not returned to work post-injury. The remaining quarter reported either part-time or alternative employment. Most subjects noted a drop in their income since the injury. Yet, no definitive trends were evident regarding satisfaction of subjects with their standard of living, implying varying perceptions of quality of life if satisfaction with living standards was to be used to gauge this phenomenon.

A change in family relationships, particularly the deterioration of the injured person's relationship with his/her children, was noted by all but one subject. Alteration of the relationship between subjects and the injured spouse/partner's | family was prevalent, with reports of greater closeness being more common than increased friction. Reallocation of the injured person's roles to spouse/partner was evident in the domains of financial decision-making, dealing with medical aids and social agencies, providing the main source of income, running the household and caring for children.

The vast majority of subjects in the current study reported that their marital relationships had changed since the injury, mainly owing to their spouses/partners' communicative changes, loss of sexual drive and personality changes, reflected particularly in their aggression and blunted emotion.

Emotional reactions of subjects to their spouses/partners' disabilities ranged from negative, for example, frustration, sadness, denial, burnout, to positive, for example, acceptance. Most subjects reported a perceived lack of independence and feeling 'tied down'. This finding was not surprising considering the frequent reports of complete or partial dependence of persons with TBI on their spouses/partners for transport, finances, decision-making and communication with unfamiliar people. The physical health of most subjects was reported to have suffered following the injury and almost all reported having been forced to postpone or cancel personal plans due to the injury. Loneliness predominated as a social consequence of a spouse/partner's injury despite the durability and support of pre-injury friendships. Finally, in terms of coping resources, psychological counselling was not reported to have been particularly effective, possibly because not many subjects had availed themselves of this service. However, supportive friends, family, religion, support groups and domestic help were believed by participants to be the most effective coping strategies.

\section{CONCLUSIONS}

Evaluation of the study was deemed necessary in order to assess its effectiveness and to gauge the value of its results. As such the limitations of the study were considered. Generalization of current results to the wider population of spouses/partners of persons with TBI in the country is limited due to the non-probability sampling, small sample size and disproportionate representation of the various ethnic, cultural and socio-economic groups in South Africa. In addition, gender effects could not be probed due to the disproportionate ratio of females to males. The small sample size also precluded the investigation of statistical correlations between variables. The questionnaire designed for data collection was quite long and detailed and required self-administration. This method of administration posed a limitation in terms of the reliability of the study since it allowed the possible misinterpretation of questions and furnishing of incomplete or sketchy responses. Ideally it should have been interviewer-administered to explain ambiguities and glean more detailed answers to open-ended questions. In addition, subjects may not necessarily have reported their beliefs accurately, being subject to social desirability bias or may have consulted other family members to assist them with the completion of the questionnaire.

Nevertheless, despite the limitations of the study, many important clinical implications emerged for speech language therapists, rehabilitation personnel, 
spouses/partners of persons with TBI, families and friends of persons with TBI and these individuals themselves.

In this study, communication difficulties were found to contribute to subjects' perceptions of decreased quality of life either directly or indirectly through their effects on marital relationships, occupational and social opportunities. Speech-language therapists thus appear to have an important role in administering direct therapy to improve the communicative abilities of individuals with TBI. Following on from the findings in this study, direct intervention might include focusing on the development of the cognitive skills underlying language dysfunction, providing alternative methods of communication such as writing or gesture, encouraging word retrieval and conversational repair strategies including identifying and repairing breakdown, as well as developing increased linguistic and pragmatic skills. Findings indicated the need for direct speech-language therapy involving both spouses/partners and persons with TBI in order to establish more effective methods of communication in an effort to prevent conversational breakdown and preserve marital harmony. In addition, the study highlighted the role of the speech-language therapist in explaining the cognitive-linguistic origin of communication problems to spouses/partners in order to increase their understanding and tolerance and to decrease their frustration. Speechlanguage therapists appeared to have a crucial role to play in providing spouses/partners with emotional support as well as the information needed to explain the consequences of the injury to family and friends. It is acknowledged that counselling might be conducted by psychologists, social workers and other rehabilitation personnel who have contact with the brain injured population and their families, not just speech-language therapists. Moreover, counselling could be broadened to include not only individual therapy but also couple counselling, family-centred approaches, and group work which might possibly be more effective intervention modes. Thus, findings appeared to have implications for all potential counsellors regardless of their discipline.

Throughout the study, findings suggested the need for healthcare workers to be sensitive to the emotional, social, marital and financial consequences of the injury for the couple. Findings regarding financial difficulties pointed to the role of members of the rehabilitation team in helping spouses/partners to access financial resources by referring them to financial advisors or to the Department of Welfare for a grant or a disability pension. The injured persons might also be helped to find alternative occupations, possibly via referral to the Association for the Physically Disabled or the Department of Labour. At this juncture in South African history, the Employment Equity Act, legislates against discrimination in the employment of persons with disabilities. The necessity for counselling of spouses/partners to assist them to come to terms with the emotional and social implications of decreased financial status was also evident in this study.

This study appeared to have implications for the marital counselling of spouses/partners of persons with TBI, indicating the need for guidance regarding future expectations and long-term coping strategies to conserve marriages. Findings seemed to indicate that counselling of the entire family, particularly the children, should be instituted to assist them to deal with the changes in family dynamics and with the altered communicative patterns of the injured person. Owing to the danger of role overload, findings pointed to the need to increase the capability of spouses/partners to deal with the burden of their new responsibilities. Rehabilitation personnel might thus assist spouses/partners to access resources that might lighten their burden, such as the hiring of a driver to assist with transport as well as equipping the injured person to resume certain roles and to undertake various jobs in the home.

The need for spouses/partners to seek or to be provided with increased opportunities for socialization was indicated, to overcome the loneliness and social difficulties that were evident in the study. In addition, rehabilitation personnel working with the target population need to be aware of the coping strategies that were found to have been successful in order to suggest them to other spouses/partners of head injured persons.

In conclusion, the current study investigated many of the aspects that were perceived to affect the quality of life of the spouses/partners of persons with TBI. Just as a seed rots in the ground before it germinates, destruction may serve to facilitate growth and development. As highlighted by LaPointe (1999, p.15), "Although quality of life may be altered, for every wreck there is a raft". By considering the various dimensions explored in the current study, rehabilitation personnel, family members and friends might contribute more significantly towards enhancing the quality of life of people whose spouses/partners have sustained traumatic brain injury, assisting them to make the most of their present situation and hence, to access their proverbial raft.

\section{REFERENCES}

Alexander, M.P., Benson, D.F, \& Stuss, D.T (1989). Frontal lobes and language. Brain and Languag, 37, 656-691.

Babbie, E. (1995). The Practice of Social Research $\left(7^{\text {th }}\right.$ edition). California: Wadsworth.

Boisclair-Papillon, R. (1993). The Family and the Person. In D. Lafond, R. DeGiovani, Y. Joanette, J. Ponzio, \& M.T. Sarno (Eds.), Living with Aphasia: Psychosocial Issues. California: Singular Publishing Group.

Bowling, A. (1995). Measuring Disease. Buckingham: Open University Press.

Brooks, D. N., \& McKinlay, W. (1983). Personality and behavioural change after severe blunt head injury' - a relative's view. Journal of Neurology, Neurosurgery and Psychiatry, 46, 336-344.

Brooks, D. N., Campsie, L., Symington, C., Beattie, A., \& McKinlay, W. (1986). The five year outcome of severe blunt head injury: relative's view. Journal of Neurology, Neurosurgery and Psychiatry, 49, 764770.

Brooks, D. N., McKinlay, W., Symington, C., Beattie, A., \& Campsie, L. (1987). Return to work within the first seven years of head injury. Brain Injury, 1, 5-19.

Burnard, P. (1991). Coping with stress in the health professions: A Practical guíde. London: Chapman and Hall.

De Picciotto, J. (2000). Personal communication. University of the Witwatersrand. 
Giles, G.M., \& Clark-Wilson, J. (1993). Brain Injury Rehabilitation. A neurofunctional approach. London: Chapman and Hall.

Hagen, C. (1984). Language Disorders in Head Trauma. In A.L Holland (Ed.), Language Disorders in Adults. United States of America: College-Hill.

Hall, K.M., Karzmark, P., Stevens, M., Englander, J., O'Hare P., \& Wright, J. (1994). Family Stressors in Traumatic Brain Injury: A Two-Year Follow-Up. Archives of Physical Medicine and Rehabilitation, 75, 876-884.

Hartley, L.L (1995). Cognitive-Communicative Abilities Following Brain Injury: A Functional Approach. California: Singular Publishing Group Incorporated.

Kagan, A. (1998). Supported conversation for adults with aphasia: Methods and resources for training conversation partners. Aphasiology, 12(9) 816-830.

Klonoff, P.S., Costa, L.D., \& Snow, W.G. (1986). Predictors and indicators of quality of life in patients with traumatic brain injury. Journal of Clinical and Experimental Neuropsychology, 5, 469-485.

Kozloff, R. (1987). Networks of social support and outcome from severe head injury. Journal of Head Trauma Rehabilitation, 2(3), 14-23.

LaPointe, L.L. (1999). Quality of Life with Aphasia Seminars in Speech and Language, 20(1), 5-16.

Levor, K.D., \& Jansen, P. (1999). The traumatic onset of disabling injury in a marriage partner: Self-reports of the experience by able-bodied spouses. Social Work, 35(2), 186-195.

Lezak, M.D. (1988). Brain damage is a family affair. Journal of Clinical and Experimental Neuropsychology,, 10(1), 111-123.

Livingston, M.G., Brooks, D.N., \& Bond, M. R. (1985). Patient outcome in the year following severe head injury and relatives' psychiatric and social functioning. Journal of Neurology, Neurosurgery and Psychiatry, 48, 876-881.

Livingston, M.G. (1987). Head injury: The relatives' response. Brain Injury, 1(1), 33-39.

Mauss-Clum, N., \& Ryan, M. (1981). Brain injury and the family. Journal of Neurosurgical Nursing, 13(4), 165-169.

McKinlay, w.W., Brooks, D.N., Bond, M.R., Martinage, D.P., \& Marshall, M. (1981). The short term outcome of severe blunt head injury as reported by relatives of the injured persons. Journal of Neurology, Neurosurgery and Psychiatry, 44, 527 533.

Nell, V., \& Brown, D.S.O. (1990). Epidemiology of traumatic brain injury in Johannesburg: Morbidity, mortality and etiology. Health Psychology Unit: Technical Report No. 1 : UNISA and HSRC.

Oddy, M., Humphrey, M., \& Uttley, D. (1978). Subjective impairment and social recovery after closed head injury. Journal of Neurology, Neurosurgery and Psychiatry, 41, 611-616.

Oddy, M., Coughlan, T., Tyerman, A., \& Jenkins, D. (1985). Social adjustment after closed head injury: A further follow-up seven years after injury. Journal of Neurology, Neurosurgery and Psychiatry, 48, 564568.

Pain, K., Dunn, M., Anderson, G., Darrah, J., \& Kratochvil, M. (1998). Quality of Life in Rehabilitation. Journal of Rehabilitation, 64(2), 5-11.
Panting, P., \& Merry, P.H. (1972). The long term rehabilitation of severe head injuries with particular reference to the need for social and medical support for the patient's family. Rehabilitation, 38, 33-37.

Penn, C., Jones, D., Schmaman, L., Vyncke, O., Watt, N., \& Fridjhon, P. (1998). Return To Work and Communication Disability: The development of a tool for South African employment contexts. Unpublished.

Ponsford, J. (1995a). Mechanisms of recovery and sequelae of traumatic brain injury. In J. Ponsford (Ed.), Traumatic Brain Injury. Rehabilitation for Everyday Adaptive Living. United Kingdom: Lawrence Erlbaum Associates.

Ponsford, J. (1995b). Working with families of traumatically brain injured individuals. In J. Ponsford (Ed.), Traumatic Brain Injury. Rehabilitation for Everyday Adaptive Living. United Kingdom: Lawrence Erlbaum Associates.

Records, N.L. (1997). Quality of Life Survey. Department of Communication Disorders. Pennysylvania: Pennsylvania State University.

Rollin, W.J. (1988). Counseling spouses of the communicatively impaired. Seminars in Speech and Language, 9(3), 269-281.

Romano, M.D. (1974). Family response to traumatic brain injury. Scandinavian Journal of Rehabilitation, $6,1-4$.

Rosin, A.J. (1977). Reactions of families of brain-injured patients who remain in a vegetative state. Scandinavian Journal of Rehabilitative Medicine, , 9, $1-5$.

Rosnow, R.L., \& Rosenthal, R. (1996). Beginning behavioral research. Englewood Cliffs, New Jersey, NJ: Prentice-Hall Inc.

Snow, P., and Ponsford, J. (1995). Assessment and managing changes in communication and interpersonal skills following traumatic brain injury. In J. Ponsford (Ed.), Traumatic Brain Injury. Rehabilitation for Everyday Adaptive Living. United Kingdom: Lawrence Erlbaum Associates.

Tate, R.L., Lulham, J.M., Broe, G.A., Strettles, B., \& Pfaff, A. (1989). Psychosocial outcome for the survivors of severe blunt head injury: The results from a consecutive series of 100 patients. Journal of Neurology, Neurosurgery and Psychiatry, 52, 117 126.

Thomsen, I. V. (1975). Evaluation and outcome of aphasia in patients with severe closed head trauma. Journal of Neurology, Neurosurgery and Psychiatry, 38, 713-718.

Thomsen, I. V. (1984). Late outcome of very severe blunt head trauma: a 10 - 15 year second follow-up. Journal of Neurology, Neurosurgery and Psychiatry, 47, 260-268.

Wertz, R.T., LaPointe, L.L., \& Rosenbek, J.C. (1984). Apraxia of Speech in Adults. United States of America : Grune and Stratton Inc.

White Paper on An Integrated National Disability Strategy (1997). Cape Town: Office of the Deputy President.

World Health Organization (WHO) (1993). WHOQOL Study Protocol: The Development of the WHO Quality of Life Assessment Instrument, MNH/PSF/93.9. Geneva, Switzerland: Division of Mental Health. 
Ylvisaker, M., \& Szekeres, S.F. (1996). Communication Disorders Associated with Closed Head Injury. In R. Chapey (Ed.), Language Intervention Strategies in Adult Aphasia ( $4^{\text {th }}$ ed.). Baltimore: Williams and Wilkins.

\section{APPENDIX A}

\section{INFORMATION SHEET}

\section{Dear Participant}

I am a final year student of Speech and Hearing Therapy at the University of the Witwatersrand and am currently involved - in research on the impact of traumatic brain injury (TBI) on the quality of life of the spouse/partner of the injured person. Research into this area has potential implications for improving our knowledge of the impact of brain injury on the quality of life of spouses/partners, the rehabilitation of persons with TBI, as well as counselling of their families.

I appreciate that you probably have a busy schedule, but would nevertheless appreciate it if you would complete the attached questionnaire and return it to me no later than when I shall personally collect it. Please place the completed questionnaire in the attached return envelope and hand it in to at Headway. The questionnaire may also be returned should you decide not to participate in the study. Please be aware that there are no right or wrong answers. All that is required is the answer that most accurately reflects your feelings and practices.

Responses will be kept strictly confidential and your anonymity will be preserved. In fact, you do not need to write your name anywhere on the questionnaire. Please note that your participation in this study is completely voluntary and that you may withdraw at any time without it being held against you in any way.

Should you wish to be given a summary of the results of the study, these will be made available on request. If you have any questions, I may be contacted at 646-2229.

Your participation is highly appreciated.

Yours sincerely

Fourth year student

Supervisor 
QUESTIONNAIRE ON THE IMPACT OF TRAUMATIC BRAIN INJURY ON QUALITY OF LIFE OF THE INJURED PERSON'S SPOUSE/PARTNER

\section{Demographic Information}

Your Age:

How long have you been married / living with your partner?

Number of children:

Age of spouse / partner:

Time in years and months since the injury:

\section{Communication}

Which of the following describes you spouse/partner's language patterns both before and after the injury? (Tick whichever is applicable).

\begin{tabular}{|l|l|l|}
\hline Before & After & \\
\hline & & Vague, sketchy, imprecise language \\
\hline & & Trouble understanding difficult spoken language \\
\hline & & Word-finding difficulty \\
\hline & & Rambling on and on, disorganized, going off on tangents \\
\hline & & Socially inappropriate language \\
\hline & & Very limited amount of speech \\
\hline & & Difficulty understanding complex written language \\
\hline & & Problems communicating in environments that are full of distractions \\
\hline & & Difficulty understanding hints (such as indirect requests) \\
\hline & & $\begin{array}{l}\text { Problems understanding humour } \\
\text { faraway in time or space) }\end{array}$ \\
\hline & & Difficulty following conversations \\
\hline
\end{tabular}

Please elaborate on the abovementioned / any other communication problems:

1. Which of the following, if any, characterises your spouse/ partner's speech: (tick the relevant block)

\begin{tabular}{|l|l|l|l|}
\hline Before & After & Not Applicable & \\
\hline & & & \\
\hline & & & laboured \\
\hline & & & too soft \\
\hline & & & stuttering \\
\hline & & & too slow \\
\hline
\end{tabular}

2. Do you find communication-with your spouse/ partner tiring?

\begin{tabular}{|l|l|l|}
\hline never & sometimes & often \\
\hline
\end{tabular}

3. Is your spouse/partner sensitive to the needs of the listener such that s/he:

\begin{tabular}{|l|l|l|}
\hline yes & no & repeats, explains or rephrases information when s/he is not understood \\
\hline yes & no & $\begin{array}{l}\text { does not overestimate or underestimate the listener's knowledge of the subject being } \\
\text { discussed }\end{array}$ \\
\hline
\end{tabular}

4. In order to convey what s/he intends to say, in addition to speech, does your spouse/partner use:

\begin{tabular}{|l|l|l|}
\hline yes & no & writing \\
\hline yes & no & gesture \\
\hline yes & no & facial expression \\
\hline
\end{tabular}


5. How often does communication break down between you and your spouse/partner?

\begin{tabular}{|l|l|l|}
\hline never & sometimes & often \\
\hline
\end{tabular}

6. Does your spouse/partner often misinterpret what you have said to him or her?

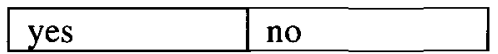

7. Have your spouse/ partner's altered communication patterns had any effect on your relationship?

\begin{tabular}{|l|l|}
\hline yes & no \\
\hline
\end{tabular}

If yes, please elaborate:

\section{Occupation and Finance}

1. Please fill in, marking with $(F)$ to indicate full-time and $(P)$ to jhatéte pârt-time.

Spouse/ partner's occupation before the injury:

Has your spouse/ partner returned to work?

Spouse/ partner's present occupation:

2. How does your present income compare to on inconte pribf to the injury?

Income has:

\begin{tabular}{|l|l|l}
\hline dropped significantly & dropere slighifly \\
\hline
\end{tabular}

3. How satisfied/disszetsfiedare you with yourspresent standard of living compared to your standard of living before the injury?
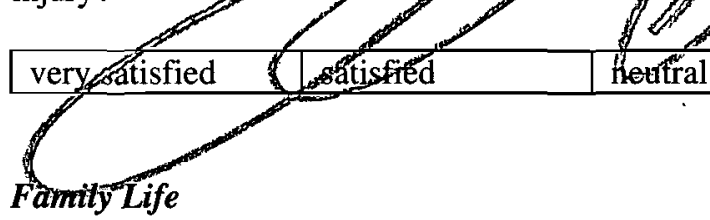

1. Has there been a change in your family relationships since the injury?

\begin{tabular}{|l|l|}
\hline yes & no \\
\hline
\end{tabular}

Please elaborate:

2. Do you feel that your relationship with your spouse/partner's family has changed since the injury?

\begin{tabular}{|l|l|}
\hline yes & no \\
\hline
\end{tabular}

If yes, please explain how it has changed:

3. How does your spouse/partner's family react to him/her?

4. Did the injury have the effect of bringing family members closer or estranging them? 
5. Does the extended family (i.e. aunts, uncles, cousins) visit as often as they did prior to the injury?

$$
\begin{array}{|l|l|}
\hline \text { yes } & \text { no } \\
\hline
\end{array}
$$

6. Does the immediate family visit as often as they did prior to the injury?

\begin{tabular}{|l|l|}
\hline yes & no \\
\hline
\end{tabular}

7. This question looks at your roles and responsibilities before and after the injury:

(Please mark your responsibilities with (My) and those of your spouse/partner with (His/Her).

\begin{tabular}{|l|l|l|}
\hline & Before the injury & After the injury \\
\hline caring for the children & & \\
\hline dealing with medical aid, social agencies & & \\
\hline making financial decisions & & \\
\hline running the household & & \\
\hline main source of income & & \\
\hline
\end{tabular}

8. Please rate your spouse/partner's ability to perform the following on a scale of $1-5(1=$ very poor; $5=$ very good $)$ :

\begin{tabular}{|l|l|l|l|l|l|}
\hline & 1 & 2 & 3 & 4 & 5 \\
\hline self-care e.g. dressing/feeding self & & & & & \\
\hline hygiene & & & & & \\
\hline household tasks & & & & & \\
\hline shopping & & & & & \\
\hline budgeting & & & & & \\
\hline driving & & & & & \\
\hline
\end{tabular}

9. How do you feel about having to take over the responsibilities of your spouse/partner?

\section{Marital Relationship}

Please complete this section irrespective of whether you are married or living in a common law relationship with your partner. (Please tick the extent to which you agree/disagree with each item).

\begin{tabular}{|l|l|l|l|l|l|}
\hline \multicolumn{1}{|c|}{ Statement } & $\begin{array}{l}\text { Strongly } \\
\text { Agree }\end{array}$ & Agree & Neutral & Disagree & $\begin{array}{l}\text { Strongly } \\
\text { Disagree }\end{array}$ \\
\hline $\begin{array}{l}\text { 1. Our marital relationship hias } \\
\text { not changed despite the injury. }\end{array}$ & & & & \\
\hline $\begin{array}{l}\text { 2. My relationship with my } \\
\text { spouse/partner has deteriorated as } \\
\text { time has passed since the injury. }\end{array}$ & & & & & \\
\hline $\begin{array}{l}\text { 3. We argue now more thaniwe } \\
\text { did before the injury. }\end{array}$ & & & & & \\
\hline $\begin{array}{l}\text { 4. I accept my spouse/partner's } \\
\text { limits. }\end{array}$ & & & & & \\
\hline $\begin{array}{l}\text { 5. I have considered divorce. } \\
\text { 6. I feel as if I am married to a } \\
\text { stranger since the injury. }\end{array}$ & & & & & \\
\hline $\begin{array}{l}\text { 7. I have a close, confiding } \\
\text { relationship with my } \\
\text { spouse/partner. }\end{array}$ & & & & & \\
\hline $\begin{array}{l}\text { 8. I keep my frustration inside } \\
\text { myself. }\end{array}$ & & & & & \\
\hline $\begin{array}{l}\text { 9. I am satisfied with my } \\
\text { marriage. }\end{array}$ & & & & & \\
\hline $\begin{array}{l}10 . \text { My spouse/partner can no } \\
\text { longer fulfil my emotional needs } \\
\text { adequately. }\end{array}$ & & & & & \\
\hline
\end{tabular}


11. What hanges in your spouse/partner (if any) since the injury, have most affected your marriage/relationship?

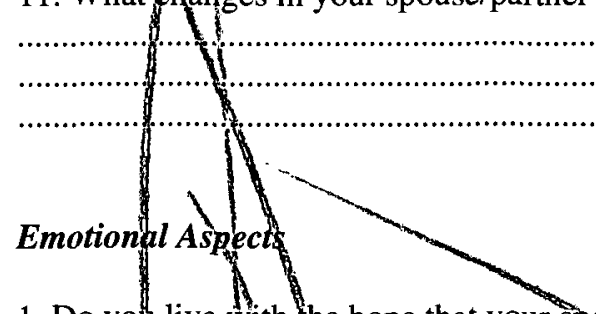

1. Do youl live With the hope that your spouse/partneswill wake up and return to his/her pre-injury self?

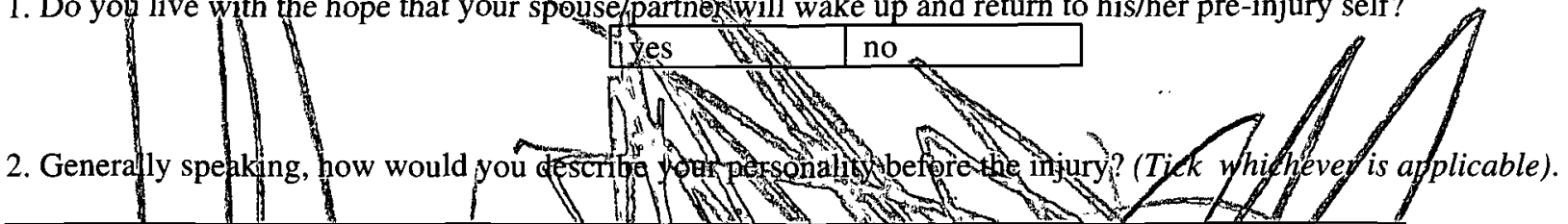

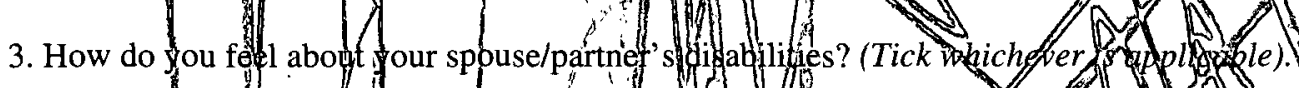

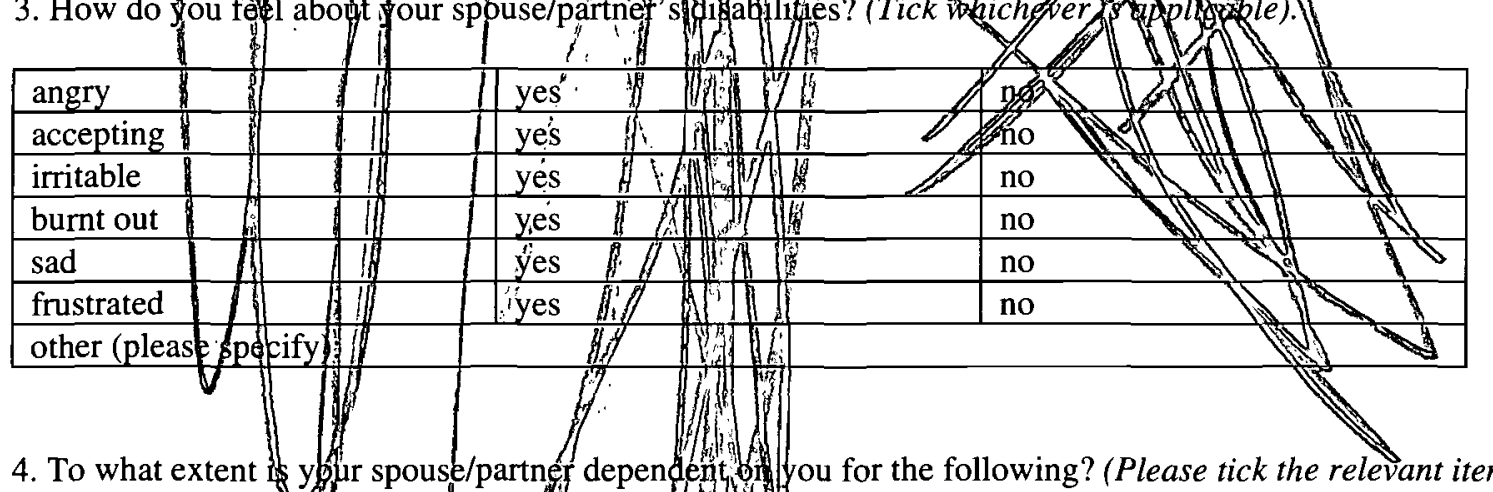

4. To what extent your spouse/partner dependent on you for the following? (Please tick the relevant item).

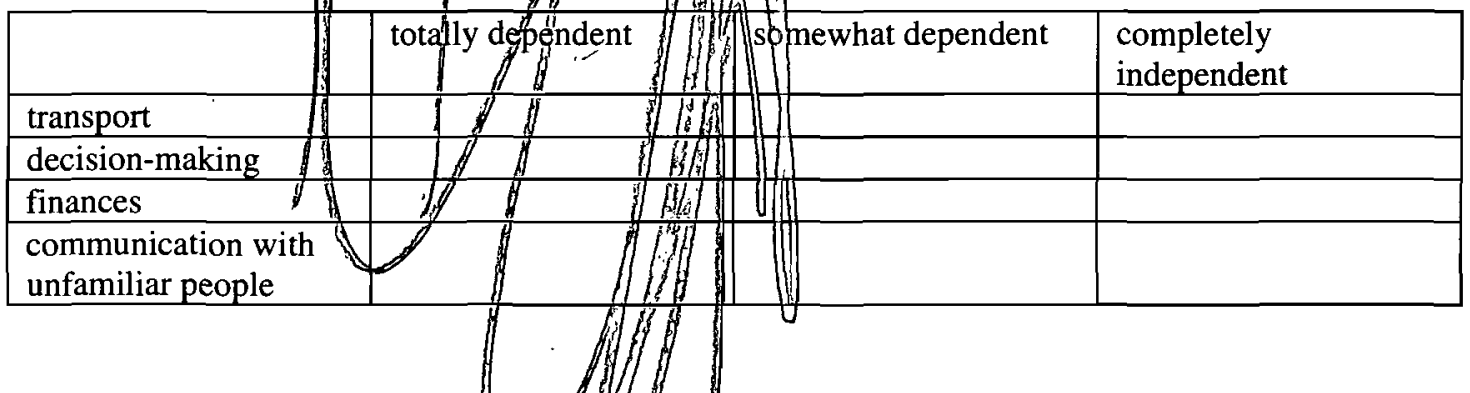

5. To what extent do you feel tied/downang lackitg in your own independence as a result of your spouse/partner's dependence?

\begin{tabular}{|c|c|}
\hline to a great extent & soménithat \\
\hline
\end{tabular}
not at all

6. Has your physical health suffereding any way a result of the stress of your spouse/partner's brain injury?

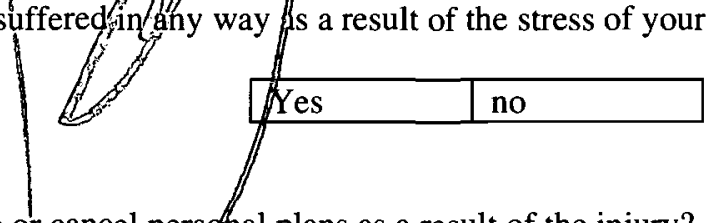

7. Have you had to postpone or cancel persohal plans as a result of the injury?

\begin{tabular}{|l|l|}
\hline Yes & No \\
\hline
\end{tabular}




\section{Social Aspects}

1. Please tick the applicable answer:

\begin{tabular}{|c|c|c|}
\hline I often feel lonely. & Yes & No \\
\hline $\begin{array}{l}\text { I feel responsible for meeting the social needs of } \\
\text { my spouse/partner. }\end{array}$ & Yes & No \\
\hline $\begin{array}{l}\text { I feel that I have lost many friends since the } \\
\text { injury. }\end{array}$ & Yes & No \\
\hline I have made many new friends since the injury. & Yes & No \\
\hline I avoid social contact. & Yes & No \\
\hline $\begin{array}{l}\text { I am embarrassed by my spouse/partner's } \\
\text { behaviour in company. }\end{array}$ & Yes & No \\
\hline $\begin{array}{l}\text { My spouse/partner says the wrong things at the } \\
\text { wrong time causing me discomfort in social } \\
\text { situations. }\end{array}$ & Yes & No \\
\hline
\end{tabular}

2. How satisfied/dissatisfied are you with your present social life in comparison with your social life before the injury?

\begin{tabular}{|l|l|l|l|l|}
\hline very satisfied & satisfied & neutral & dissatisfied & very dissatisfied \\
\hline
\end{tabular}

\section{Coping Resources}

1. Please mark the extent of the contribution of the following to your coping with the consequences of the injury? (Please tick those which are applicable).

\begin{tabular}{|l|l|l|l|}
\hline & very helpful & somewhat helpful & not at all helpful \\
\hline psychological counselling & & & \\
\hline religion & & & \\
\hline support groups & & & \\
\hline domestic help & & & \\
\hline friends & & & \\
\hline medication & & & \\
\hline
\end{tabular}

2. What, if anything, has helped you most to deal with the stresses resulting from the traumatic brain injury?

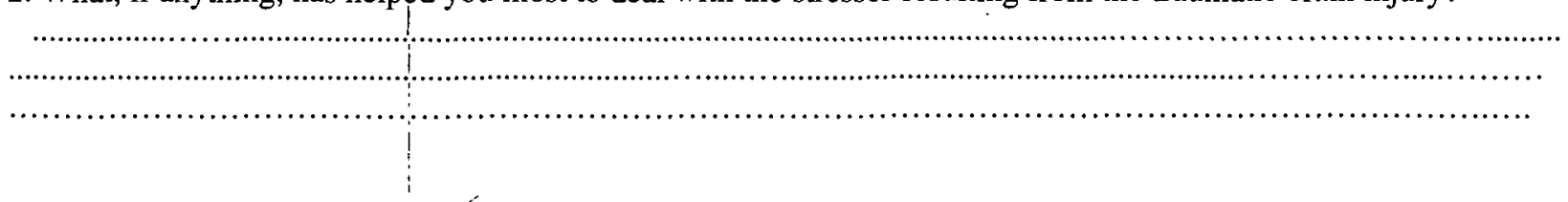

Thank you very much for your co-operation. 


\section{INFORMATION FOR CONTRIBUTORS}

\section{Nature of publication}

The South African Journal of Communication Disorders publishes reports and papers concerned with research, and critically evaluative theoretical and philosophical conceptual issues dealing with aspects of human communication and its disorders, service provision, training and policy.

The South African Journal of Communication Disorde will not accept material which has been published elsewhere or that is currently uñder review by other publications.

\section{Manuscript style and requirements}

- Articles must he accompanied by a covering letter providing the author's address, telephone and fax numbers and e- mail address.

- Articles must be typed on A4 pages in double spacing and in a font size of 12

- Three print outs of the article must be submitted.

- ONE exact copy of the article on disk must be submitted Filenames must include the first, author's initials and a clearly identifiable key word and must he type-written on the last line of the last page of the Reference list (for retrieval purposes only)

- Articles must not exceedd 30 pages.

$\therefore$ The title page of ONE must contain:

- Title of the article.

- Full names of the authors:

- Institutional affiliation.

- Abstract of the article in the language of the anticlé.

- The title page of the rembining TWO capies must NOT con- tain the authorls namels or institutional affiliations.

- Each article must contain a abstract of no more than 200 words.

- All abstracts mușt be in ENGLISH, irrespective of the language in which the article was written. - Each article must provide 5- KEY WORD forind
purposes.

- All contributions are required to follow strietly, the style specified in the Publicatidh Manual of the American Psychological Association (APA Pub. Man., 1983).

- Headings are NOT NUMBERED. The order of importance is indicated as follows:

- Main heading in capitals and bold print.

- Sub-headings in capitals, hold and italic priht.

- Sub-subheadings in upper and lower case bold and italic print.

- Sub-sub-sub-heading in upper and lower case hold print.

- Major headings, where applicable, must be in the orde of INTRODUCTION, METHOD, RESULTS, DISCUS:SION, CONCLUSION, ACKNOWLEDGEMENTS, REFERENCES.

- All paragraphs should be indented.

- All tables, figures and illustrations must he numbered and provided with titles.

- The title of tables, which appear above, and of figures, which appear below, must he concise but explanatory.

$\because$ Allow for $50-75 \%$ reduction in printing of tables, figures an illustrations.

- Each table, figure or illustration must appear on a SEPARATE page and be print ready. Preferable NOT printed on colour printers.

- Do not include more than 10 tables, figures or illustrations.

\section{REFERENCES}

- References must he cifed.in the text by surname of the

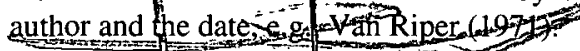

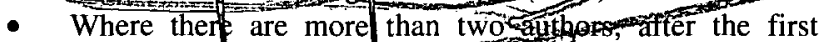
scurrence

- The names of alf auth is mustsappes in the Reference List, which hust wertlised so strict alphabetical order in triplespacin on the ond of the article.

- All references (mud ancluded in the List, including secondarosourdes, (APA Pub. Man. 1983, p. 13.)

- Qpty acceptable abbrraviafions of journals may be used,

Sfe DSI-1 ABS KRACYS, October; or The World List of Sctentific Periodichls

- The number of recrence hould not exceed much more

than 30 , unless specifically yarranted.

\section{EXAMALES}

Itocke, Jul (1983). Clinic 1 Psychology: The explanation and treatment of spech sound djsorder. J. Speech hear Disord., 48 339. 341

Pentod, J.P (1985). Speech dischimination testing. In J. Katz (Ed.), Handbdokofclinicalatudiology $\quad\left(3^{\text {rd }} \quad\right.$ ed.). Baltimore: Willians \& Wilkins. $\Rightarrow$

Davis, \& \& Wilcox, M.J. (1985). Adult aphasia rehabilitation: Apy (ied kragmatics. San Diego, CA: College-Hill.

\section{EDITING}

- Article nust be revised for grammar and style prior to sub mision.

- The manf script style of the article must be strictly accprding to the guidelines provided.

- Ond articles complying with the above requirements will be ficcepted for review.

\section{REVIEWING SYSTEM}

- The peer review of refereeing system is employed as a mothod of quality control of this publication.

- Per reviewers are selected by the editor based on their e. pertise in the field and each article is sent to two if dependent reviewers to assess the quality of the hanuscript's scientific and technical content.

- The blind peer review system is employed during which the names of the author/authors are not disclosed to the

reviewers.

The editor retains the final responsibility for decisions regarding revision, acceptance or rejection of the manuscript.

\section{DEADLINE FOR CONTRIBUTIONS: 30 'h June each year}

QUERIES, CORRESPONDENCE \& MANUSCRIPTS: should he addressed to The Editor, South African Journal of Communiction Disorders South African Speech-LanguageHearing Association, Postnet Suite 62, Private Bag X1, Florida Hills, 17l'́. Tel. 011675 3555, Fax. 0116753785.

\section{Copyright}

The copyright of all articles printed in The South African Journal of Communication Disorders is reserved by-The South African Speech-Language-Hearing Association (SASLHA). 